\title{
SEPARATION/PRECONCENTRATION AND DETERMINATION OF TRACE AMOUNTS OF PALLADIUM USING MODIFIED ALUMINA COATED MAGNETITE NANOPARTICLES WITHOUT CHELATING AGENT
}

\author{
MOHAMMAD ALI KARIMI I,2, , ABDOLHAMID HATEFI-MEHRJARDI I,2, MANIJEH KAFI ${ }^{2}$
}

\author{
IDepartment of Chemistry, Payame Noor University, P.O. Box 19395-4697, Tehran, Iran \\ ${ }^{2}$ Department of Chemistry \& Nanoscience and Nanotechnology Research Laboratory (NNRL), Payame Noor University, P.O. Box 78185-34, Sirjan, Iran
}

(Received: May 28, 2012 - Accepted: January 16, 2014)

\begin{abstract}
In the present article, a simple, rapid, selective, sensitive and economical method has been developed for the separation/preconcentration of the trace amounts of $\mathrm{Pd}(\mathrm{II})$ in different real samples using alumina coated magnetite nanoparticles modified by sodium dodecyl sulfate and its determination by flame atomic absorption spectrometry after eluting with $1.0 \mathrm{~mol} \mathrm{~L}^{-1}$ thiourea. Under the optimal experimental conditions, the preconcentration factor, detection limit, linear range and relative standard deviation of $\mathrm{Pd}(\mathrm{II})$ were 280 (for $700 \mathrm{~mL}$ of sample solution), $4.3 \mathrm{ng} \mathrm{mL}-1,6.0-120.0 \mathrm{ng} \mathrm{mL}^{-1}$ and $4.6 \%$ (for $10 \mathrm{ng} \mathrm{mL}^{-1}$, $\mathrm{n}=10$ ), respectively.
\end{abstract}

Keywords: Solid-phase extraction; Alumina-coated magnetite nanoparticles; Palladium(II); Flame atomic absorption spectrometry

\section{INTRODUCTION}

Palladium is widely used in metallurgy, in various chemical syntheses, production of dental alloys, heat and corrosion resistance apparatus, medicinal devices, jewelry manufacture, electronic, telephone circuits and electrodes for high quality spark plugs ${ }^{1-3}$. This noble metal is a metal of economic importance; however, as a new pollutant in the environment, all its compounds should be regarded as highly toxic and carcinogenic to humans ${ }^{4}$. Therefore, separation/ preconcentration and determination of $\mathrm{Pd}(\mathrm{II})$ is greatly interested in environmental compartments such as soil, road dust, wastewater and different water samples. Among various methods proposed for the separation and enrichment of Pd(II) solid phase extraction (SPE) is the most widely applied technique due to rapid phase separation, simple and higher preconcentration factor $^{5-13}$.

At present, nano-sized materials such as $\mathrm{TiO}_{2}, \mathrm{Al}_{2} \mathrm{O}_{3}, \mathrm{ZrO}_{2}, \mathrm{SiO}_{2}$ and carbon nanotubes have more important in SPE due to their special property of high adsorption capacity ${ }^{14-19}$. But separation of these particles from aqueous medium is difficult because of very small dimension and high dispersion. Combining nanoparticles adsorption with magnetic separation is good for avoid passing through the column in conventional SPE methods. Magnetite nanoparticles (MNPs) are suitable for this propose and surface modification of MNPs is a challenged key for this application ${ }^{20-34}$. Several analytical methods such as spectrophotometry ${ }^{35}$, flame atomic absorption spectrometry (FAAS) ${ }^{36}$, inductively coupled plasma-mass spectrometry (ICP-MS) ${ }^{37}$, inductively coupled plasma-optical emission spectrometry (ICP-OES) ${ }^{38}$ and electrochemical methods ${ }^{39}$ have been used for determination of trace amounts of palladium.

In our previous works, the abilities of alumina coated magnetite nanoparticles (ACMNPs) for separation/preconcentration of $\mathrm{Ag}(\mathrm{I})$ and $\mathrm{Pb}(\mathrm{II})$ were investigated ${ }^{40-42}$. In this study, we will explore the possibility of only SDS immobilized on ACMNPs without chelating agent to act as SPE sorbent for the separation/preconcentration of trace level of Pd(II) from environmental samples prior to determination by flame atomic absorption spectrometry (FAAS).

\section{EXPERIMENTAL}

\subsection{Apparatus and reagents}

Scanning electron microscope (LEO 1455VP SEM), Fourier transform infrared spectrometer (FT-IR Prestige-21, Shimadzu) and vibrating sample magnetometer (VSM 7400 Model Lake-Shore) were used to characterize the structure of the prepared ACMNPs and SDS-ACMNPs. A flame atomic absorption spectrometer (PG Instrument, England) was used with a lead hollowcathode-lamp at an operating current of $15 \mathrm{~mA}$. Other instruments used were: ultrasonic bath (S60H Elmasonic, Germany), mechanical stirrer (Heidolph, RZR2020), orbital shaker (Ika, KS130 Basic), an electronic analytical balance (Adam, AA220LA) was used for weighting the solid materials. In addition, for magnetic separations a strong neodymium-iron-boron $\left(\mathrm{Nd}_{2} \mathrm{Fe}_{12} \mathrm{~B}\right)$ magnet (1.2 $\mathrm{T}, 2.5 \mathrm{~cm} \times 5 \mathrm{~cm} \times 10 \mathrm{~cm}$ ) was used.

All reagents used were of analytical grade and all solutions were prepared by using triple distilled and deionized water. A stock solution of $1000 \mu \mathrm{g}$ $\mathrm{mL}^{-1}$ of $\mathrm{Pd}(\mathrm{II})$ was prepared by dissolving $0.169 \mathrm{~g}$ of $\mathrm{PdCl}_{2}$ in $10 \mathrm{~mL}$ of concentrate $\mathrm{HCl}$ and was diluted to $100 \mathrm{~mL}$. Working solutions were obtained by further diluting the stock solution to the required concentrations before use. Sodium dodecylsulfate (SDS), ferrous chloride $\left(\mathrm{FeCl}_{2} \cdot 4 \mathrm{H}_{2} \mathrm{O}\right.$ ), ferric chloride $\left(\mathrm{FeCl}_{3} \cdot 6 \mathrm{H}_{2} \mathrm{O}\right)$, aluminum isopropoxide, ethanol, nitric acid, hydrochloric acid, thiourea and sodium hydroxide were used without further purification processes.

\subsection{Preparation of SDS-ACMNPs}

ACMNPs were prepared according to our previous works. ${ }^{40-42}$ A SDS solution was prepared by dissolving $200.0 \mathrm{mg}$ SDS in $100 \mathrm{~mL}$ deionized water. Ten milliliters of this solution was added to $10 \mathrm{~mL}$ water containing $0.2 \mathrm{~g}$ of ACMNPs. The $\mathrm{pH}$ of this suspension was adjusted to 2.0 by drop-wise addition of $\mathrm{HNO}_{3}\left(0.1 \mathrm{~mol} \mathrm{~L}^{-1}\right)$ solution. The mixed solution was shaken for $15 \mathrm{~min}$ and then separated from the reaction medium under the magnetic field, and rinsed with $10 \mathrm{~mL}$ pure water. This product was used as sorbent for palladium ions.

2.3 General procedure

The procedure for the magnetic SPE of Pd(II) is as follows: $10 \mathrm{~mL}$ of $\operatorname{Pd}(\mathrm{II})$ solution $\left(5 \mu \mathrm{g} \mathrm{mL}^{-1}\right)$ was added to SDS/ACMNPs from above section, subsequently the $\mathrm{pH}$ value was adjusted to 6.0 with phosphate buffer and the solution was shaken for $15 \mathrm{~min}$ to facilitate adsorption of the palladium ions onto the NPs. Then the magnetite adsorbents were separated easily and quickly using magnet and decanted directly. Subsequently, $2.0 \mathrm{~mL}$ of thiourea solution $\left(1.0 \mathrm{~mol} \mathrm{~L}^{-1}\right)$ as eluent was added. Finally, the magnet was used again to settle the magnetic nanoparticles and the eluate was separated for FAAS analysis.

2.4 Sample preparation procedure for water

Water samples (i.e., tap water, spring water and river water), were filtered after collection through filter paper (Whatman, no. 4) to remove suspended particulate matter and basicified to a pH of about 9.5 with ammonia/ammonium chloride buffer prior to storage in polyethylene containers for use. The SPE procedure was carried out as described in the general procedure.

\subsection{Sample preparation procedure for road dust}

The four to 10 grams of road dust samples were collected from four different roadsides with dense traffic in Sirjan. The samples were digested with a mixture of $20 \mathrm{~mL}$ concentrated $\mathrm{HCl}$ and $5 \mathrm{~mL}$ of concentrated $\mathrm{HNO}_{3}$ at room temperature, then they were heated to $100^{\circ} \mathrm{C}$ for $5 \mathrm{~h}$. The mixtures were evaporated to dryness and then $10 \mathrm{~mL}$ of above acid mixture was added to the residue and evaporated to dryness again. After this, $20 \mathrm{~mL}$ of deionized water were added to the beaker and the insoluble parts were filtered. The $\mathrm{pH}$ was adjusted to 9.5 with ammonia/ammonium chloride buffer and the total volumes were made up to $20 \mathrm{~mL}$ with deionized water in four beakers and the solutions were taken for separation/preconcentration procedure.

\section{RESULTS AND DISCUSSION}

\subsection{Characterization of ACMNPs and SDS-ACMNPs}

It is most important that the ACMNPs as sorbent should possess suitable magnetic property. This was studied by measuring the hysteresis and remanence curve by means of a vibrating sample magnetometer (VSM). The curve shows that ACMNPs with value of large saturation magnetization of 9.34 
emu $\mathrm{g}^{-1}$ exhibit typical superparamagnetic behavior due to no hysteresis (Fig. 1). Therefore, sorbent of ACMNPs is sufficient for magnetic separation with a conventional magnet.

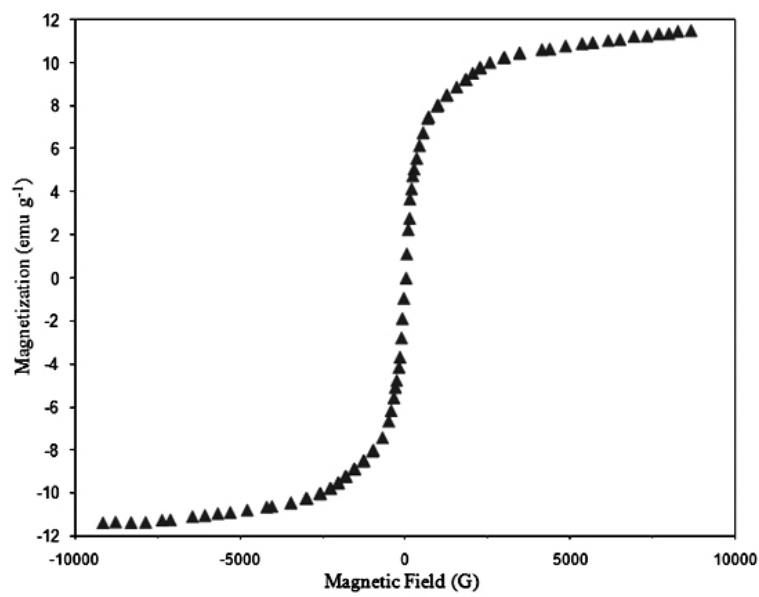

Fig. 1. The magnetic behavior of ACMNPs.

A scanning electron microscope (SEM) was used to examine the surfaces of the MNPs and ACMNPs as adsorbent (Fig. 2). The image of Fig. 2b illustrates a highly porous morphology of adsorbent with uniform size distribution of the nanospheres.
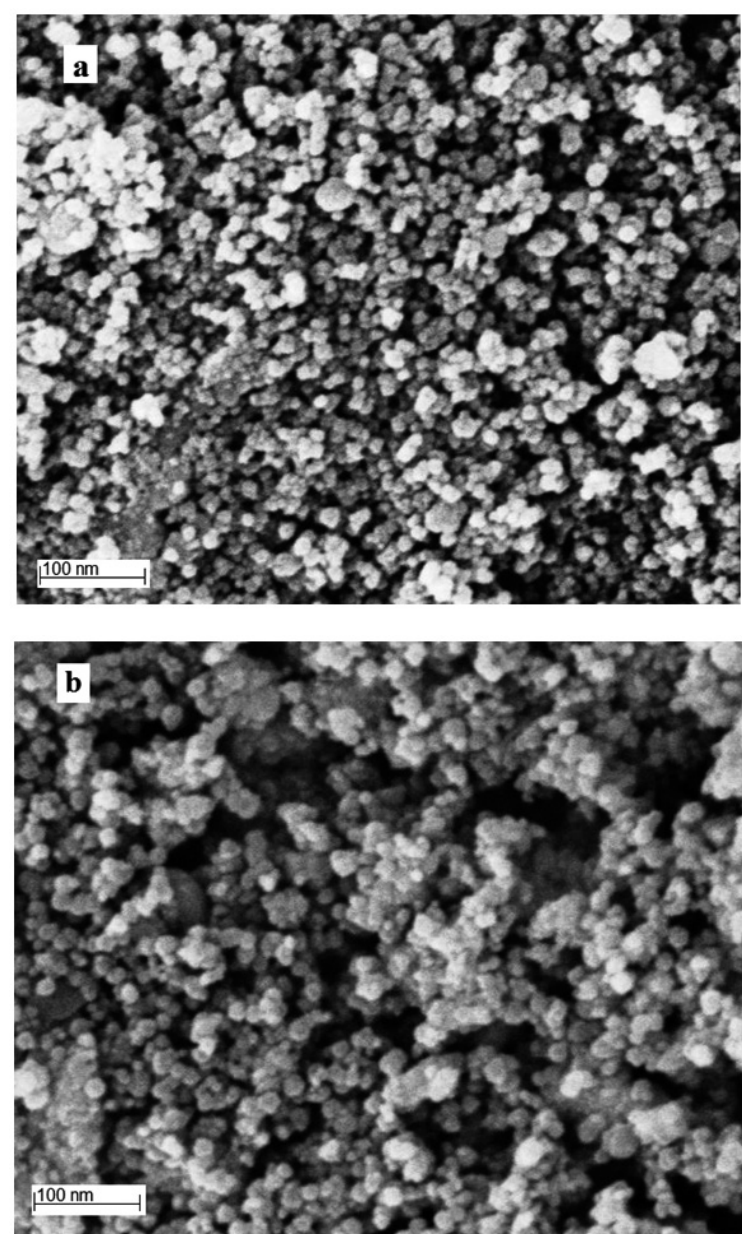

Fig. 2. SEM images of MNPs (a) and ACMNPs (b).
The XRD pattern for the ACMNPs showed eight characteristic peaks for $\mathrm{Fe}_{3} \mathrm{O}_{4}$ and $\mathrm{Al}_{2} \mathrm{O}_{3}$ according the software database file. The average crystallite size (D) is calculated to be $18.9 \pm 2 \mathrm{~nm}$ for ACMNPs using the Debye-Scherrer formula of $\mathrm{D}=\mathrm{K} \lambda /(\beta \cos \theta)$, where $\mathrm{K}, \lambda, \beta$ and $\theta$ are the Scherrer constant $(\mathrm{K}=0.89)$, the X-ray wavelength $\left(\lambda=1.5406 \mathrm{~A}^{\circ}\right)$, the full peak width at half maximum (FWHM) and the Bragg diffraction angle, respectively ${ }^{43}$. The result is well consistent with that of SEM analysis.

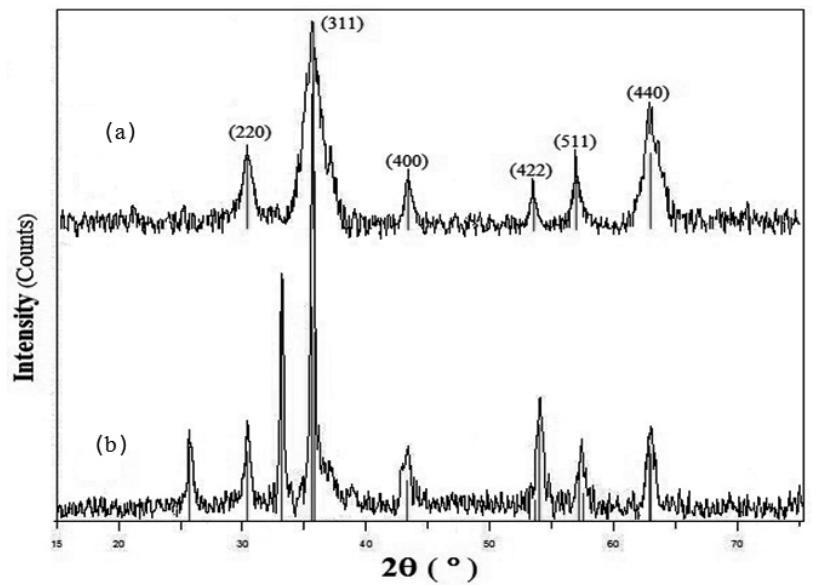

Fig. 3. XRD patterns for the naked $\mathrm{Fe}_{3} \mathrm{O}_{4}$ (a) and alumina coated $\mathrm{Fe}_{3} \mathrm{O}_{4}$ nanoparticles (b).

\subsection{Effect of pH and SDS amount}

ACMNPs have positively charged surfaces in highly acidic solutions that can strongly adsorb a negatively charged surfactant such as SDS. The SDS would form hemimicelles or admicelles on alumina by strong adsorption and it can strongly adsorb on the positively charged ACMNPs surface to form aggregates ${ }^{44}$. A concentration of SDS, below its critical micellar concentration (CMC, $8 \mathrm{mmol} \mathrm{L}^{-1}$ ), was used. Above this concentration, the excess of SDS would form micelles in the aqueous solution, which were not adsorbed on alumina surfaces. When the solution was acidified, the ad-micelles could trap Pd(II). Therefore influence of various amounts of 25, 50, 60, 75, 90, 100, 125, 150 and $200 \mathrm{mg}$ SDS on adsorption of palladium ions through the ACMNPs substrate was investigated. The results showed that maximum adsorption was obtained when $100 \mathrm{mg}$ SDS used. Thus, this amount was selected as the optimum concentration of SDS for further studies.

In order to establish the effect of $\mathrm{pH}$ on the adsorption of Pd(II), the batch equilibrium studies at different $\mathrm{pH}$ values were carried out in the range of 2.0-11.0. Results show that the maximum removal of $\mathrm{Pd}(\mathrm{II})$ on the adsorbents was observed at range of 3.5-7.5 by shaking the solution containing SDS and ACMNPs for $10 \mathrm{~min}$. When solution was acidified, SDS would form hemimicelles on ACMNPs by strong sorption and this micelles could trap Pd(II) ions. At $\mathrm{pH}>7.5$ the metal complex forms and results in precipitation and therefore the separation may not be due to adsorption. Therefore, the $\mathrm{pH}$ value of 6.0 was used as $\mathrm{pH}$ optimum for further study.

3.3 Standing and magnetic separation time

The effect of time on the adsorption of palladium on the SDS-ACMNPs was studied. When the ACMNPs were isolated immediately without a standing process, the recovery of $\mathrm{Pd}(\mathrm{II})$ was $67 \%$. But, when the standing time was adjusted to $5,10,15,20$ and $30 \mathrm{~min}$, recoveries were improved to $87,93,96$, 96 and $96 \%$. Therefore, standing times of 15 min was selected as the optimum time to achieve satisfactory adsorption and better recovery of palladium ions.

3.4 Effect of sample volume, nanoparticles amount and desorption conditions

In order to obtain a preconcentration factor, a larger volume of sample solution is required. For study the effect of sample volume on the recovery of palladium ions, the sample solutions in the range of $50-800 \mathrm{~mL}$ containing 5.0 $\mu \mathrm{g}$ of palladium ions were operated according to the general procedure and eluted using $2.0 \mathrm{~mL}$ of thiourea $\left(1.0 \mathrm{~mol} \mathrm{~L}^{-1}\right)$. In the sample volumes higher than $700 \mathrm{~mL}$, the recovery decreased. Consequently, a preconcentration factor of 280 could be attained for quantitative recovery of $95 \pm 2 \%$ of Pd(II) when the sample volume was $700 \mathrm{~mL}$.

The effect of nanoparticles amount on the quantitative extraction of Pd(II) was studied by applying various amounts of SDS/ACMNPs (from 10 to 300 
$\mathrm{mg}$ ). The extraction was found to be quantitative when $200 \mathrm{mg}$ or more. Experiments were carried out with $200 \mathrm{mg}$ modified nanoparticles.

Different eluents of thiourea, thiosulphate, acetate, $\mathrm{HCl}, \mathrm{HNO}_{3}, \mathrm{H}_{2} \mathrm{SO}_{4}$ and $\mathrm{NaOH}$ at various concentrations were tested in order to elute the adsorbed palladium from the sorbent. It was found that $2.0 \mathrm{~mL}$ of thiourea with a concentration of $1.0 \mathrm{~mol} \mathrm{~L}^{-1}$ was sufficient for quantitative recovery of adsorbed Pd(II).

Table 1 Comparison of the characteristic data between typical published methods and the proposed method for separation/preconcentration and determination of $\mathrm{Pd}(\mathrm{II})$.

\begin{tabular}{|c|c|c|c|c|c|c|c|}
\hline Sorbent & $\begin{array}{l}\text { Detection } \\
\text { method }\end{array}$ & $\begin{array}{l}\text { Preconcentration } \\
\text { factor }\end{array}$ & $\begin{array}{l}\text { Sorbent } \\
\text { capacity } \\
\left(\mathrm{mg} \mathrm{g}^{-1}\right)\end{array}$ & RSD (\%) & $\begin{array}{l}\text { Linear range } \\
\left(\mathrm{ng} \mathrm{mL}^{-1}\right)\end{array}$ & $\begin{array}{c}\text { Detection } \\
\text { limit } \\
\left(\mathrm{ng} \mathrm{mL}^{-1}\right)\end{array}$ & Ref \\
\hline $\begin{array}{l}\text { Saccharomyces cerevisiae/ calcium } \\
\text { alginate beads }\end{array}$ & GFAAS $^{\mathrm{a}}$ & N.R. ${ }^{b}$ & 10.0 & 4.6 & N.R. & 7.0 & {$[5]$} \\
\hline Thiophene-2-carbaldehyde/Silica & $\mathrm{ICP}-O E S^{\mathrm{c}}$ & 100 & 5.0 & 3.2 & $1-1000$ & 0.2 & [6] \\
\hline $\begin{array}{l}5 \text { (p-dimethylaminobenzylidene) } \\
\text { rhodanine/Silica gel-polyethylene glycol }\end{array}$ & FAAS & 125 & 0.99 & 4 & $2-80$ & 0.54 & [7] \\
\hline Pyridine/ Nano alumina & FAAS & 60 & 37 & 0.8 & N.R. & 0.6 & [8] \\
\hline Aspergillus sp./Cellex-T resin & ETAAS $^{d}$ & 11.5 & 1.24 & 5.0 & $0.5-5.6$ & 0.012 & [9] \\
\hline Cysteine/Silica gel & ICP-OES & 100 & N.R & $6-8$ & N.R & 0.02 & {$[10]$} \\
\hline Murexide/Halloysite nanotubes & ICP-OES & 120 & 42.86 & 3.1 & N.R. & 0.29 & {$[11]$} \\
\hline Oxidized MWCNTs ${ }^{\mathrm{e}}$ & FAAS & 165 & 15.7 & 5.3 & $1-200$ & 0.3 & [12] \\
\hline 2,6-Diaminopyridine /Activated carbon & ICP-AES $^{f}$ & 150 & 38.5 & $<3$ & N.R. & 0.33 & [13] \\
\hline SDS/ACMNPs & FAAS & 280 & 8.3 & 4.6 & $6.0-120.0$ & 4.3 & This work \\
\hline
\end{tabular}

${ }^{a}$ Graphite furnace atomic absorption spectrometry; ${ }^{\mathrm{b}}$ Not reported; ${ }^{\mathrm{c}}$ Inductively coupled plasma-optical emission spectrometry; ${ }^{\mathrm{d}}$ Electrothermal atomic absorption spectrometry; ${ }^{\mathrm{e}}$ Multi-walled carbon nanotubes; ${ }^{\mathrm{f}}$ Inductively coupled plasma-atomic emission spectrometry

Table 2 Recoveries results for Pd(II) determination in different real samples of road dust, river, tap and spring waters.

\begin{tabular}{|c|c|c|c|}
\hline \multirow{2}{*}{ Sample } & \multicolumn{2}{|c|}{$\mathrm{Pd}(\mathrm{II}) / \mu \mathrm{g} \mathrm{mL} \mathrm{L}^{-1}$} & \multirow{2}{*}{$\begin{array}{l}\text { Recovery } \\
(\%)\end{array}$} \\
\hline & Added & Found $^{\mathrm{a}}$ & \\
\hline \multirow{3}{*}{$\begin{array}{l}\text { River water (Tezerg, } \\
\text { Hajiabad) }\end{array}$} & 0 & N.D & ----- \\
\hline & 5 & $5.20( \pm 0.3)$ & 104.0 \\
\hline & 10 & $9.80( \pm 0.3)$ & 99.8 \\
\hline \multirow{3}{*}{ Tap water (Sirjan) } & 0 & N.D & ----- \\
\hline & 5 & $4.70( \pm 0.1)$ & 94.0 \\
\hline & 10 & $9.35( \pm 0.2)$ & 93.5 \\
\hline \multirow[b]{2}{*}{$\begin{array}{l}\text { Spring water (Saadatabad, } \\
\text { Sirjan) }\end{array}$} & 0 & N.D & ------ \\
\hline & $\begin{array}{c}5 \\
10\end{array}$ & $\begin{array}{l}4.87( \pm 0.4) \\
9.91( \pm 0.3)\end{array}$ & $\begin{array}{l}97.4 \\
99.1\end{array}$ \\
\hline $\begin{array}{l}\text { Road dust ( Sirjan-Bandar } \\
\text { Abbas) No. } 1\end{array}$ & $\begin{array}{c}0 \\
5 \\
10\end{array}$ & $\begin{array}{c}0.21 \\
5.44( \pm 0.4) \\
10.37( \pm 0.2)\end{array}$ & $\begin{array}{l}----- \\
104.6 \\
101.1\end{array}$ \\
\hline $\begin{array}{l}\text { Road dust ( Sirjan-Bandar } \\
\text { Abbas) No. } 2\end{array}$ & $\begin{array}{c}0 \\
5 \\
10\end{array}$ & $\begin{array}{c}0.27 \\
5.42( \pm 0.3) \\
10.30( \pm 0.3)\end{array}$ & $\begin{array}{l}----- \\
105.0 \\
103.0\end{array}$ \\
\hline $\begin{array}{l}\text { Road dust ( Sirjan-Bandar } \\
\text { Abbas) No. } 3\end{array}$ & $\begin{array}{c}0 \\
5 \\
10\end{array}$ & $\begin{array}{c}0.36 \\
5.36( \pm 0.2) \\
10.55( \pm 0.3)\end{array}$ & $\begin{array}{l}----- \\
100.0 \\
101.9\end{array}$ \\
\hline $\begin{array}{l}\text { Road dust ( Sirjan-Bandar } \\
\text { Abbas) No. } 4\end{array}$ & $\begin{array}{c}0 \\
5 \\
10\end{array}$ & $\begin{array}{c}0.26 \\
5.44( \pm 0.4) \\
10.76( \pm 0.4)\end{array}$ & $\begin{array}{l}------ \\
103.6 \\
105.0\end{array}$ \\
\hline
\end{tabular}

\footnotetext{
${ }^{\text {a }}$ Average of three determination \pm standard deviation.
}

\subsection{Interference study}

The study of interference ions was performed by a standard mixture solution containing $5.0 \mu \mathrm{g} \mathrm{mL}-1$ of $\mathrm{Pd}(\mathrm{II})$ and a certain amount of foreign ions. The following excesses of ions do not interfere (i.e., caused a relative error of less than 5\%): less than a 1000 -fold (largest amount tested) amount of $\mathrm{Na}^{+}, \mathrm{K}^{+}$, $\mathrm{F}^{-}, \mathrm{Cl}^{-}, \mathrm{Br}^{-}, \mathrm{NO}_{3}^{-}, \mathrm{SO}_{4}^{2-}, \mathrm{ClO}_{4}^{-}$; a 500 -fold amount of $\mathrm{NH}_{4}^{+}, \mathrm{Ba}^{2+}, \mathrm{Ca}^{2+}, \mathrm{Ni}^{2+}$, $\mathrm{Zn}^{2+}, \mathrm{Co}^{2+}, \mathrm{Mg}^{2+}, \mathrm{Cu}^{2+}, \mathrm{Pb}^{2+}, \mathrm{Fe}^{2+}$; a 50 -fold amount of $\mathrm{Cr}^{3+}, \mathrm{Fe}^{3+}, \mathrm{Al}^{3+}$ and a 10 -fold amount of $\mathrm{Zr}^{4+}$.

\subsection{Adsorption capacity and adsorbent regeneration}

Adsorption capacity study used here was adapted from the method recommended by Maquieira et al ${ }^{45}$. The static sorption capacity of SDS/ ACMNPs was found to be $8.3 \mathrm{mg} \mathrm{g}^{-1}$ for palladium ions. In this research, it also was found that the adsorbent can be reused up to three times without loss of analytical performance. Considering that $4.0 \mathrm{~g}$ of modified ACMNPs could be prepared in one batch and only $200 \mathrm{mg}$ of ACMNPs was used for one extraction operation, this reusability time is acceptable.

3.7 Analytical performance and method validation

Under the optimal experimental conditions, the analytical features of the method such as limit of detection (LOD), linear range of the calibration curve and precision were examined. The LOD of the proposed method based on three times the standard deviation of the blank $\left(3 \mathrm{~S}_{\mathrm{b}}\right)$ was $4.3 \mathrm{ng} \mathrm{mL}^{-1}$. The linear range of calibration curve for $\mathrm{Pd}(\mathrm{II})$ was $6.0-120.0 \mathrm{ng} \mathrm{mL}^{-1}$ with a correlation coefficient of 0.9915 . The regression equation was $\mathrm{A}=0.0238 C_{\mathrm{Pd}}+0.0366(n$ $=7$ ), where $C_{\mathrm{Pd}}$ is the concentration of $\mathrm{Pd}$ (II) in $\mathrm{ng} \mathrm{mL}^{-1}$ and $A$ is the absorbance. The relative standard deviation (RSD) for 10 replicate measurements of 10.0 $\mathrm{ng} \mathrm{mL} \mathrm{m}^{-1}$ of palladium ions was $4.6 \%$ which indicated a reproducible response. Table 1 shows a comparison of the proposed method with other reported SPE methods. It could be seen that some obtained values for the proposed method are as or better than some of the previously reported methods.

\subsection{Analytical Applications}

The performance and reliability of the method for the analysis of real samples was checked by determination of $\mathrm{Pd}(\mathrm{II})$ content in different waters and road dust samples (Table 2). According to these results, the added Pd(II) can be quantitatively recovered from different waters and road dust samples by the extraction procedure. These results demonstrate the applicability of the extraction procedure for palladium in real samples. 


\section{CONCLUSIONS}

It has been demonstrated that the modified ACMNPs provides a new and fast route for separation/preconcentration and determination of Pd(II) using FAAS technique in different samples. This sorbent was successfully applied for convenient, fast, simple and efficient enrichment of trace amounts of palladium ions from road dust and different water samples. The main benefits of this methodology are: no use of toxic organic solvents, simplicity and high capacity of sorbent, preconcentration factor, fast adsorption and low cost. Magnetic separation greatly shortened the analysis time of the method. Furthermore, it avoids the time-consuming column passing (about $1 \mathrm{~h}$ in conventional SPE method) and filtration operation, and no clean-up steps were required.

\section{ACKNOWLEDGEMENTS}

The authors would like to express their appreciations to Professor Afsaneh Safavi for her valuable discussion and useful suggestions. This research was supported by the Nanoscience and Nanotechnology Research Laboratory (NNRL) of Payame Noor University of Sirjan.

\section{REFERENCES}

1 K. Pyrzynska, Anal. Sci. 23, 631 (2007)

2 M. Duran, Y. Kara, G.K. Akyildiz, A. Ozdemir, Bull. Environ. Contam. Toxicol. 78, 395, (2007)

3 K. Szentmihalyi, M. Then, Acta Aliment. 36, 231, (2007)

4 O. Akoto, J. Adiyiah, Int. J. Environ. Sci. 4, 211, (2007)

5 B.G. Zylkiewicz, M. Kozlowska, Anal. Chim. Acta 539, 61, (2005)

6 M.R. Jamali, Y. Assadi, F. Shemirani, M. Salavati-Niasari, Talanta 71, 1524, (2007)

7 S. Rastegarzadeh, N. Pourreza, A.R. Kiasat, H. Yahyavi, Microchim. Acta 170, 135, (2010)

8 E. Najafi, O. Sadeghi, N. Tavassoli, H.R. Lotfi. Anal. Sci. 26, 874, (2010)

9 S. Woinska, B. Godlewska-Zylkiewicz, Spectrochim. Acta B 66, 522, (2011)

10 A.R. Mahdaviana, M.A. Mirrahimi, Chem. Eng. J. 159, 264, (2010)

11 R. Li, Q. He, Z. Hu, S. Zhang, L. Zhang, X. Chang, Anal. Chim. Acta 713, 136, (2012)

12 C.G. Yuan, Y. Zhang, S. Wang, A. Chang, Microchim. Acta 173, 361, (2011)

13 D. Li, X. Chang, Z. Hu, Q. Wang, Z. Tu, R. Li, Microchim. Acta 174, 131, (2011)

14 P. Liang, Y. Qin, B. Hu, T. Peng, Z. Jiang, Anal. Chim. Acta 440, 207, (2001)

15 M. Ezoddin, F. Shemirani, K.H. Abdi, M.K. Saghezchi, M.R. Jamali, J. Hazard. Mater. 178, 900, (2010)

16 H. Erdogan, O. Yalcınkaya, A.R. Turker, Desalination 280, 391, (2011)
17 L. Zhang, X. Chang, Z. Hu, L. Zhang, J. Shi, R. Gao, Microchim. Acta 168, $79,(2010)$

18 L.M. Ravelo-Pérez, A.V. Herrera-Herrera, J. Hernández-Borges, M.A. Rodríguez-Delgado, J. Chromatogr. A 1217, 2618, (2010)

19 S.G. Ozcan, N. Satiroglu, M. Soylak, Food Chem. Toxicol. 48, 2401, (2010)

20 M. Safaríkova, I. Safarík, J. Magn. Magn. Mater. 194, 108, (1999)

21 J. Hu, G. Chen, M.C. Irene, Water Res. 39, 4528, (2005)

22 P. Ashtari, K. Wang, X. Yang, S. Huang, Y. Yamini, Anal. Chim. Acta 550, 18, (2005)

23 S. Banerjee, D. Chen, J. Hazar. Mater. 147, 792, (2007)

24 M.R. Jamali, Y. Assadi, F. Shemirani, M. Salavati-Niasari, Talanta 71, 1524, (2007)

25 H. Parham, N. Rahbar, J. Pharm. Biomed. Anal. 50, 58, (2009)

26 B. Zargar, H. Parham, A. Hatamie, Talanta 77, 1328, (2009)

27 L. Sun, X. Sun, X. Du, Y. Yue, L. Chen, H. Xu, Q. Zeng, H. Wang, L. Ding, Anal. Chim. Acta 665, 185, (2010)

28 A.R. Mahdaviana, M.A. Mirrahimi, Chem. Engin. J. 159, 264, (2010)

29 M.H. Mashhadizadeh, Z. Karami, J. Hazard. Mater. 190, 1023, (2011)

30 A.E. Karatapanis, Y. Fiamegos, C.D. Stalikas, Talanta 84, 834, (2011)

31 S. Shariati, M. Faraji, Y. Yamini, A.A. Rajabi, Desnilation 270, 160, (2011)

32 H. Eskandari, M.R. Shariati, Anal. Chim. Acta 665, 185, (2011)

33 G. Cheng, M. He, H. Peng, B. Hu, Talanta 88, 507, (2012)

34 H. Parham, B. Zargar, R. Shiralipour, J. Hazard. Mater. 205-206, 94, (2012)

35 V. Kaur, A.K. Malik, N. Verma, Turk. J. Chem. 34, 295, (2010)

36 M. Imamoglu, V. Gunes, Atom. Spectrosc. 33, 205, (2012)

37 W.H. Hsu, S.J. Jiang, A.C. Sahayam, Anal. Chim. Acta 794, 15, (2013)

38 W. Nischkauer, E. Herincs, M. Puschenreiter, W. Wenzel, A. Limbeck, Spectrochim. Acta, B 89, 60, (2013)

39 R. Langyan, S.P. Khatkar, Asian J. Chem. 25, 1376, (2013)

40 M.A. Karimi, S.Z. Mohammadi, A. Mohadesi, A. Hatefi-Mehrjardi, M. Mazloum-Ardakani, L. Sotudehnia Korani, A. Askarpour Kabir, Sci. Iran. 18, 790, (2011)

41 M.A. Karimi, A. Hatefi-Mehrjardi, S.Z. Mohammadi, A. Mohadesi, M. Mazloum-Ardakani, M.R. Hormozi Nezhad, A. Askarpour Kabir, J. Iran. Chem. Soc. 9, 171, (2012)

42 M.A. Karimi, A. Hatefi-Mehrjardi, M. Mazloum-Ardakani, A. Askarpour Kabir, M. Kazemipour, N. Afsahi, Int. J. Environ. Anal. Chem. 92, 1325 , (2012)

43 R.Y. Hong, T.T. Pan, Y.P. Han, H.Z. Li, J. Ding, S.J. Han, J. Magn. Magn. Mater. 310, 37, (2007)

44 M. Hiraide, J. Iwasawa, H. Kawaguchi, Talanta 44, 231, (1997)

45 A. Maquieira, H.A.M. Elmahadi, R. Puchades, Anal. Chem. 66, 3632, (1994) 